\title{
Corynoxine isomers decrease levels of amyloid- $\beta$ peptide and amyloid- $\beta$ precursor protein by promoting autophagy and lysosome biogenesis
}

\author{
Siva Sundara Kumar Durairajan*, Yingyu Huang, Leilei Chen, Juxian Song, Liangfeng Liu, Min Li \\ From Molecular Neurodegeneration: Basic biology and disease pathways \\ Cannes, France. 10-12 September 2013
}

\section{Background}

One of the key histopathological features of Alzheimer's disease $(\mathrm{AD})$ is the formation of neuritic plaques characterized by accumulation of amyloid $\beta$-peptide $(A \beta)$ derived from amyloid precursor protein (APP). Impairment of the autophagy-lysosomal degradation pathway has been associated with AD. Recently we have identified a novel natural autophagy inducer, corynoxine B (Cory-B), a major oxindole alkaloid from the Chinese medicinal plant Uncaria rhynchophylla (Miq.) Jacks (Gouteng in Chinese). In this study, we have also established that corynoxine (Cory) and its isomer of Cory- $\mathrm{B}$, not only increases basal level of autophagy but also increases the lysosomal activity in neuronal cell lines. Interestingly Cory but not Cory-B showed the enhanced lysosomal activities.

\section{Materials and methods}

N2a cell stably expressing Swedish APP (N2aSwedAPP) cells were treated with Cory or Cory-B at different dosage and time-course. Elisa was performed to measure the total $\mathrm{A} \beta$ in the supernatant of cell cutlture. Double immunostaining on N2aSwedAPP cells were performed using by carboxy terminal fragment (CTF) of APP (CT15) and LC-3 antibodies. Tg2567 mice at the age of 8 months, randomly distributed into Cory-B-treated Tg2567 group (Cory-B group) or Tg2567 group, and age matched nonTg mice (C57BL/6, NT group) were assigned as aging control. Mice were intraperitoneally administered Cory-B $(20 \mathrm{mg} / \mathrm{kg} / \mathrm{d})$ or vehicle $(0.9 \%$ saline $)$ once daily except weekends for 2 months. Cell and brain lysates were prepared for Western blot assay.

\section{Results}

We observed a dose-dependent significant decrease in $A \beta$ in cells incubated with Cory or Cory-B for $24 \mathrm{~h}$. Next we found that Cory- or Cory-B mediated decreases in $A \beta$ are due to changes in its precursor protein APP, by measuring the level of full-length APP and APP-CTFs in cell lysates from N2a-sSwedAPP. Simultaneously, we also found that Cory and Cory B dose-dependently increased levels of LC3-II, an autophagy specific marker in N2aSwedAPP cells. Furthermore we found that Cory- or Cory-B induced LC3-II was enhanced by lysosome inhibitor chloroquine (CQ) and slightly decreased by autophagy inhibitor 3-methyladenine. We have confirmed this finding in immunocytochemistry of N2aSwedAPP cells with CT15 and LC3 antibody. Further, we found that only Cory but not Cory- $\mathrm{B}$ dose dependently increased the mature Cathepsin D. Cory treatment simultaneously increased Lamp-1 and decreased APP staining. Importantly, Cory dosedependently induced the nuclear translocation of Transcription Factor EB (TFEB). In cell signaling studies, we found that Cory but not Cory-B time dependently decreased mTORC-1 activity via p70SK and GSK pathway. Two months of Cory-B treatment significantly decreased FI-APP and APP-CTF in Tg2567 ( $<<0.05)$. Cory- $\mathrm{B}$ treatment did not influence the levels of FI-APP in NT mice.

\section{Conclusions}

Our data reveal that corynoxine isomers reduce $A \beta$ through an increase of the degradation of APP and its CTF by activation of the autophagy/lysosomal pathway. 

and take full advantage of:

- Convenient online submission

- Thorough peer review

- No space constraints or color figure charges

- Immediate publication on acceptance

- Inclusion in PubMed, CAS, Scopus and Google Scholar

- Research which is freely available for redistribution 